\title{
MISCELLANEOUS.
}

\section{On the Reproductive Apparatus of the Ephemeridæ.}

By M. JoLY.

Male Genital Apparatus.-So far as we know, since Swammerdam, no one has studied the internal structure of the genital apparatus of the Ephemeridæ. Léon Dufour confesses his almost complete ignorance on the subject of this apparatus *. F. J. Pictet says nothing about it, or, at least, he speaks only of the external organs assisting in copulation. The Rev. A. E. Eaton, in his monograph $\uparrow$ does not say a single word about the internal genital organs.

We regret that we have been unable to multiply our dissections sufficiently to leave no important gap in our anatomical investigation. We have sought in vain for the male organs in a great number of individuals of that sex belonging to Palingenia virgo, which flew about in the evening in the light of the lamps along the quays of the Garonne $\ddagger$. It is probable that in them these organs were already shrivelled up immediately after the accomplishment of fecundation.

But in the males of Baëtis sulphurea, which we have several times dissected, we have very clearly seen the internal genital apparatus, formed of two testes, or milts as Swammerdam calls them §, placed one on each side of the digestive tube.

They present the form of two elongated, clavate sacs, recurved into a hook at their apex, pure white, and with gibbosities on their surface. The membrane forming their outer envelope is of extreme delicacy, and contains large vesicles or spermatic capsules (cellulesmères, Godard; ceufs mâles, C. Robin), which in their turn are filled with rounded spermogenous cells (cellules-filles, Godard; cellules embryonnaires mâles, C. Robin), in many of which we have distinctly seen the spermatozoids rolled upon themselves just like minute snakes.

The testicular tube or sac is bordered along its inner side by a duct, to which the spermatic capsules appear to be suspended by a short pedicle, like grapes to their stalks ; they thus open to the deferent duct, which in its turn is continued into an ejaculatory duct which penetrates into one of the two corresponding penises, traverses its whole length, and terminates at the exterior orifice to pour out its contents there. I say one of the two penises, because, by an excep-

* "Recherches anatomiques et physiologiques sur les Orthoptères, les Hyménoptères, et les Névroptères," Mém. des Savants étrangers, tome vii. (1841) p. 581.

† "A Monograph of Ephemeridæ," in Trans. Ent. Soc. Lond. 1871, pp. $41-44$ and $49-53$.

$\ddagger$ In this species the males have always appeared to us to be much fewer than the females.

$\S$ Swammerdam believed that the ova of the Ephemeræ are fecundated after the manner of those of tishes-that is to say, without previous copulation. 
tion which is as rare amongst insects as it is common in the Crustacea, the male Ephemeridæ are provided with two copulatory organs *.

These organs are attached to the penultimate inferior half-segment of the abdomen. They are of horny consistency, of a curved form, hollow within, and pierced at their free extremity with an orifice through which the seminal fluid escapes during fecundation. They are situated at some distance within the two corneous, curved, and quadriarticulate pieces which form the forceps, or copulatory armature by which the male holds the female during copulation, and which, from the point of view of philosophical anatomy, is nothing but an abdominal foot converted into an organ of prehension.

The author of the 'Biblia Naturæ' has represented the testes of Palingenia longicauda in the form of two elongated tubes with the surface uneven, as if mamillated. He adds that at their posterior part they are furnished with two smaller sacs, which he believes to be seminal vesicles; but he dees not mention either the deferent ducts or the ejaculatory canals. Now these ducts and canals exist, as we have ascertained by dissecting several individuals of $P$. longicauda, obtained direct from Holland, but preserved for some time in alcohol. A maceration of two or three hours in slightly tepid water has enabled us to isolate the testes of this Ephemerid without much difficulty, and thus to make sure that their structure is identical with that of the testes of Baêtis.

We have sought in vain for the supposed seminal vesicles described by Swammerdam. Léon Dufour states that he could not find the least trace of them in Ephemera nigrimana. We are therefore led to believe that the celebrated Dutch naturalist mistook for seminal vesicles simple adipose sacs like those which we have ourselves observed in Baëtis sulphurea, and which, at the first glance, have some little resemblance to seminal vesicles.

However this may be, our dissections, repeated several times, enable us to affirm that no seminal vesicles exist in the Ephemeridæ that we have studied. As to the testes, they have struck us by their comparatively considerable size, and especially by their resemblance in form and their analogy of structure to those of the Libellulinæ, and even to those of the higher Vertebrata in this respect, that, like the latter, they are found in final analysis to consist of a tube containing spermatic capsules (oufs mâles, C. Robin) lodging smaller cells (cellules embryonnaires máles, C. Robin), in the interior of which the spermatozoids are developed.

Female Genital Apparatus. - In several thousands of individuals

* In assuming the existence of two penises in the Ephemeræ we shall, perhaps, seem to some entomologists to be committing a serious mistake, and to be taking for penises the pieces (which are often absent) to which Léon Dufour has given the name of "volselles," and which, according to him, are constituent parts of the copulatory armature. But besides that these "volselles" are often deficient in insects, we have, to support the correctness of our determination, the indisputable fact of the excretory seminal duct passing through these organs which we regard as two penises. 
collected still living among the carcasses of $P$. virgo which strewed the banks of the Garonne, we have not observed a single one the ovaries of which were not almost completely empty. On opening the abdomen after oviposition, we have only found a double sac of considerable capacity, formed by a membrane of extreme delicacy, receiving at its interior part a great number of ovigerous sheaths of three or four chambers containing an equal number of ova in course of formation. Other ova, more advanced in their development, and already furnished with the sort of hood or cap which covers the extremity opposite to that where the head of the embryo will be, are accumulated in greater or less numbers in the great sac into which the ovigerous sheaths open *.

Is there a special oviduct for each of these two sacs? Léon Dufour says that the sac which constitutes the ovary terminates posteriorly by a tubular neck, which unites with its congener to form a very short oviduct. Swammerdam says nothing of any such arrangement; nor have we ever seen any thing of the kind; so that we are more disposed to think that there are two oviducts as there are two penises, and that these two oviducts open separately, in the membrane which unites the seventh abdominal segment to the eighth.-Comptes Rendus, October 30, 1876, p. 809.

\section{On the Nervous System and Muscles of the Echinida.}

\section{By M. L. Frederica.}

1. Nervous System.-Notwithstanding the labours of Tiedemann, Van Beneden, Krohn, J. Müller, Valentin, Baudelot, C. K. Hoffmann, and Lovén, the nervous system of the sea-urchins still presents many obscure points. The investigations that I made this summer at Roscoff on the nervous system of Echinus sphara and Toxopneustes lividus have furnished the following results.

Anatomy.-The pentagonal nervous ring that surrounds the œsophagus, and the five ambulacral cords that start from it, are continued within a system of canals which has hitherto been unobserved. This anatomical peculiarity is easily verified, even without the aid of sections, on the cords which run along the ambulacral zones in the interior of the test. Here we find two greatly flattened superposed canals: the inner one is the ambulacral canal; the outer one, which is intimately united with the other, contains the ambulacral nerve in the form of a dark-coloured flattened ribbon. The nervous cord floats freely in this sheath, and is only kept in its place by the series of nervous branches which it emits on each side towards the base of the ambulacral vesicles. The envelope of the nervous system is firmly united, but only on the middle line, with

* Swammerdam remarked the extreme smallness of the eggs of the Ephemeræ: he says, "Ovula cæterum stupendæ sunt parvitatis, et vix animadverti queunt." It is, in fact, by this minuteness, that he explains the necessity of the long sojourn (trienni spatio) that the larvæ issuing from the egg's have to make in the water before changing into perfect insects (see 'Biblia Naturæ,' tom. ii. p. 255). 


\section{$2 \mathrm{BHL}$ Biodiversity Heritage Library}

Joly, M. 1877. "On the reproductive apparatus of the Ephemeridæ." The Annals and magazine of natural history; zoology, botany, and geology 19, 193-195. https://doi.org/10.1080/00222937708682116.

View This Item Online: $\underline{\text { https://www.biodiversitylibrary.org/item/85173 }}$

DOI: https://doi.org/10.1080/00222937708682116

Permalink: https://www.biodiversitylibrary.org/partpdf/64202

\section{Holding Institution}

Smithsonian Libraries

\section{Sponsored by}

Smithsonian

\section{Copyright \& Reuse}

Copyright Status: Public domain. The BHL considers that this work is no longer under copyright protection.

This document was created from content at the Biodiversity Heritage Library, the world's largest open access digital library for biodiversity literature and archives. Visit BHL at https://www.biodiversitylibrary.org. 